\title{
First record of Modicogryllus frontalis (Orthoptera: Gryllidae) from the Baltic coast
}

\author{
Stanislav RADA and Filip TRNKA \\ Department of Ecology and Environmental Sciences, Faculty of Science, Palacký University Olomouc, Šlechtitelů 27, \\ 78371 Olomouc - Holice, Czech Republic; e-mail: stanislav.rada@seznam.cz
}

\begin{abstract}
A nymph of cricket Modicogryllus frontalis was found near Czołpino (northern Poland) on sandy dunes close to the Baltic coast. It is the northernmost locality of the species in Poland and in Europe and the first record from the Baltic Coast. The distribution of the species in Central Europe is summarized and presented on the map.
\end{abstract}

Key words: Central Europe, distribution, Eastern Cricket, Słowiński National Park

\section{INTRODUCTION}

The Eastern Cricket Modicogryllus frontalis (Fieber, 1844) is a small species of cricket with distinctive yellow strip on its forehead. It inhabits xerothermic habitats, such as steppes, fallows, clay-pits, sand-pits and quarries (Liana 2004, Kočárek et al. 2013). It is endangered and declining in Poland and other Central European countries, mainly because of destruction and overgrowing of its habitats (Liana 2004).

North-western edge of the M. frontalis distribution runs through France, Germany, Czech Republic, Poland and Lithuania (Fig. 1). This continues further on east as far as Mongolia; on south reaches to Bosnia (Kočárek et al. 2013). The westernmost locality of $M$. frontalis lies in southern France (Aellen \& Thorens 1997). There was also a recent finding near Colmar just few kilometres from German border (Rust et al. 2012). In Germany, the species had several localities in southern part of the country (Maas et al. 2002) and currently lives only in BadenWürttemberg (Brandt 1997, Buchweitz \& Trautner 1997). In the Czech Republic, M. frontalis dwells on numerous localities in southern Moravia (Holuša et al. 2013). It went extinct on localities in Bohemia during last 2-3 decades (Holuša et al. 2013), but a new finding was made on fly ash deposit of the Tušimice Power Plant (Tropek 2013). In Poland, the species was distributed across large parts of the country, but majority of localities vanished (Liana 2004). One isolated locality in Lithuania, was previously considered to be the farthest to the north for this species (Budrys \& Pakalniškis 2007).

\section{StUdy AREA, MATERIAL AND METHODS}

Material examined: northern Poland, Słowiński National Park, Czołpino, sand dunes (Wydma Czołpińska) surrounded by coastal forest, 54.726 N, 17.262 E, 5th August 2015, 1 nymph, leg. F. Trnka, det. et coll. S. Rada. The nymph was caught accidentally in open sandy habitat within Ammophila arenaria vegetation (Fig. 2). It was $9 \mathrm{~mm}$ long and clearly identifiable as $M$. frontalis by characteristic yellow strip on its forehead (Figs $3 \& 4$ ). The possibility of confusion with $M$. truncatus (Tarbinsky, 1940) is rather unlikely, because the north-western boundary of $M$. truncatus range reaches barely the south-eastern Hungary (Szövényi 2011). 


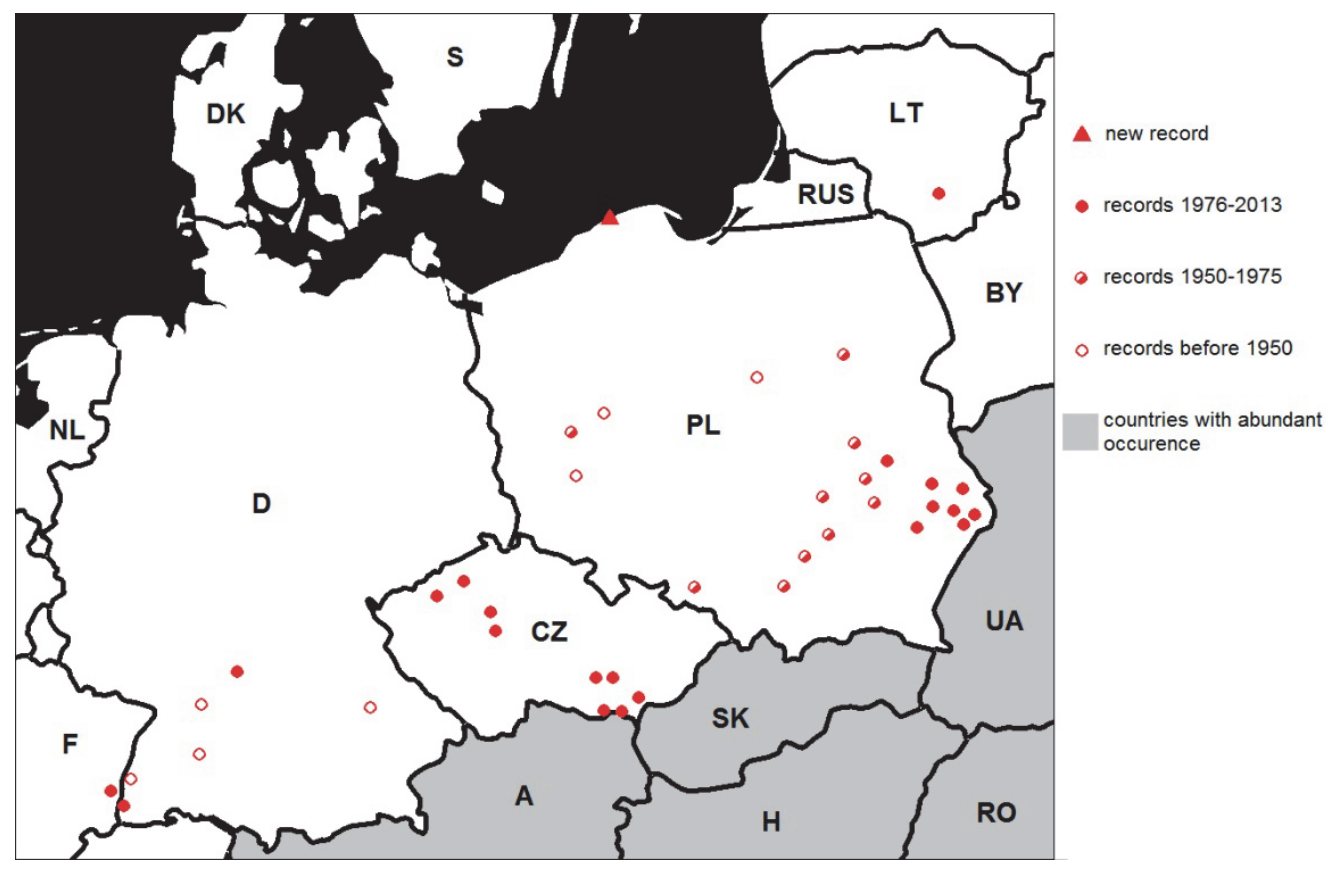

Fig. 1. Occurrences of Modicogryllus frontalis in Central Europe (north-western edge of its distribution). Prepared according to Aellen \& Thorens (1997), Maas et al. (2002), Liana (2004), Budrys \& Pakalniškis (2007), Rust (2012), Holuša et al. (2013), Tropek (2013), Heller (2016). In case of more records close together, only one dot was drawn. Codes of countries: A - Austria; BY - Belarus; CZ - Czech Republic; D - Germany; DK - Denmark; F - France; H Hungary; LT - Lithuania; NL - Netherlands; PL - Poland; RO - Romania; RUS - Russia; S - Sweden; SK Slovakia; UA - Ukraine.

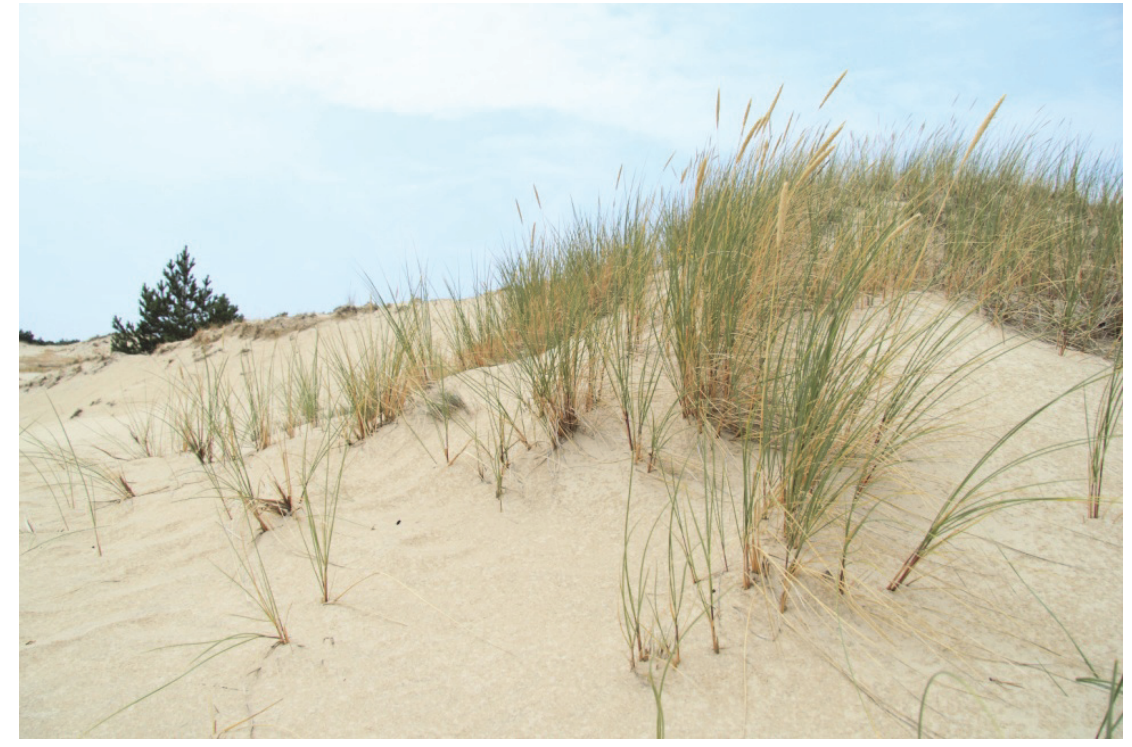

Fig 2. The locality near Czołpino, where the specimen of Modicogryllus frontalis was caught on 5th August 2015. Photo by F. Trnka 

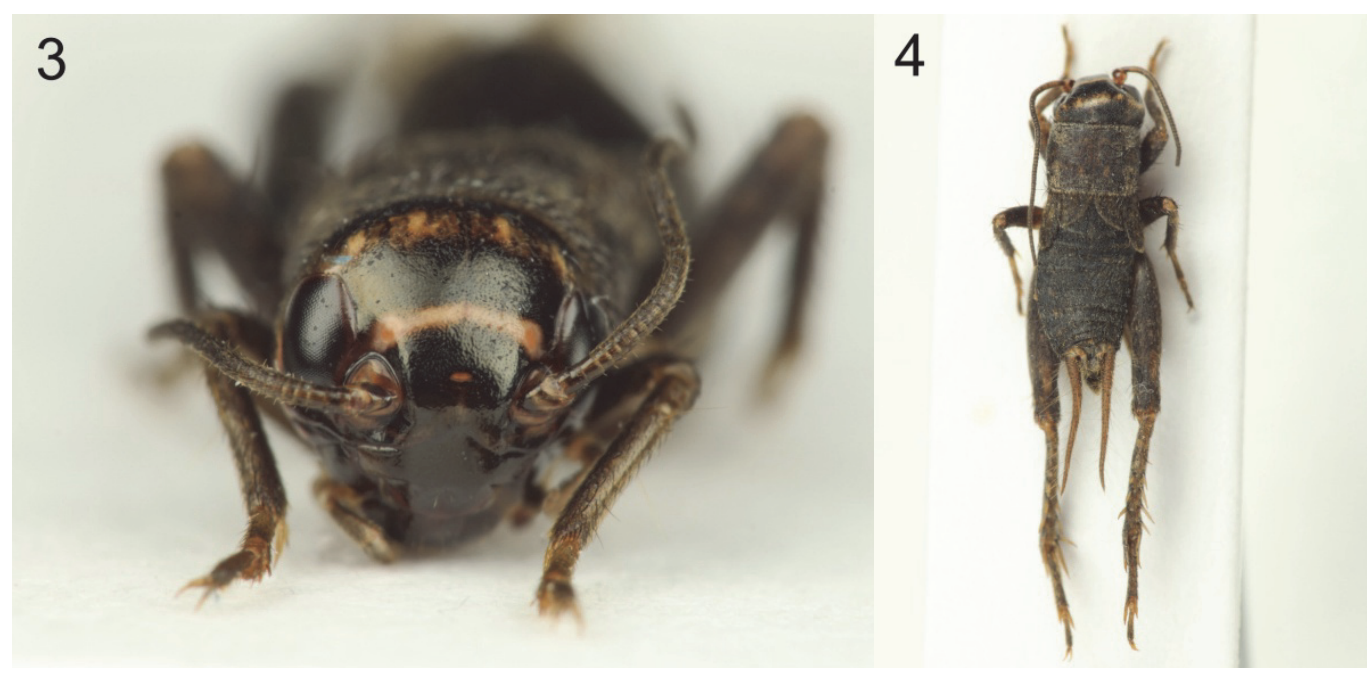

Figs 3 \& 4. Modicogryllus frontalis nymph collected near Czołpino on 5th August 2015, 3 - frontal view; 4 -dorsal view. Photos by F. Trnka.

\section{RESULTS AND DISCUSSION}

Our finding represents the northernmost locality of $M$. frontalis in Poland. It is also the northernmost finding in Europe, being few minutes more to north than locality of the species in Lithuania (Budrys \& Pakalniškis 2007). It is remarkable that M. frontalis was never found in northern Poland before. The species disappeared from majority of formerly known localities in Poland and seemed to be surviving only in south-eastern Poland (Fig. 1). We can only speculate, if it was overlooked in northern Poland or if there was spreading of the species to north. Anthropogenic introduction is also possible, but rather less likely.

Furthermore, it is the first finding of $M$. frontalis along Baltic coast (the site is approx. 1 $\mathrm{km}$ away from the coastline). The species often occurs on sandy habitats, but it is rather continental faunal element and a record from sea coast is unusual. The locality of Czołpino should be examined to find out size of the population and habitat preference of the species there. Although M. frontalis was not found on the nearby Hel Peninsula (Kuřavová 2014) and, certainly, is not widespread along the coast, we encourage entomologists to look for this endangered species along the Baltic coast.

\section{ACKNOWLEDGEMENTS}

We thank to Robert Vlk, Kateřina Kuřavová and Pavel Marhoul for consultations. We also very appreciate comments and advise of anonymous reviewers and the help of editor.

\section{REFERENCES}

AELlen V. \& ThORENS P. 1997. Modicogryllus frontalis (Fieber, 1844), un nouveau Grillon pour la faune française découvert dans le Var (Orthoptera, Gryllidae). L'Entomologiste 53: 241-246.

BRANDT D. 1997. Einige Beobachtungen zu Vorkommen, Ökologie und Biologie der Östlichen Grille Modicogryllus frontalis (Fieber, 1844) in Kiesgruben der Südlichen Oberrheinebene. Articulata 12: 211-218.

BuCHWEITZ M. \& TRAUTNER J. 1997. In vino veritas? Zum Vorkommen der Östlichen Grille Modicogryllus frontalis (Fieber, 1844) im Jagsttal (Baden-Württemberg). Articulata 12: 201-209.

BuDRYS E. \& PAKALNIŠKIS S. 2007. The Orthoptera (Insecta) of Lithuania. Acta Zoologica Lituanica 17: $105-115$. 
HeLlER K.H. 2016. Fauna Europaea: Modicogryllus frontalis. Fauna Europaea, version 2.6. Available at http://www.fauna-eu.org

HoluŠA J., KoČÁrek P., VlK R. \& Marhoul P. 2013. Annotated checklist of the grasshoppers and crickets (Orthoptera) of the Czech Republic. Zootaxa 3616: 437-460.

KoČÁREK P., Holuša J., VlK R. \& MARhoul P. 2013. Orthopterans of the Czech Republic [Rovnokřídlí (Insecta: Orthoptera) České republiky]. Academia, Praha, 288 pp. [in Czech]

KUŘAVOVÁ K. 2014. Orthopteran fauna of the Hel peninsula in Poland. Fragmenta Faunistica 57: 41-46.

LIANA A. 2004. Modicogryllus frontalis. In: GŁOWACIŃSKIZ. \& NOWACKI J. (eds.), Polish red data book of animals - Invertebrates. Institute of Nature Conservation PAS, Kraków. Available at http://www.iop.krakow.pl/pckz/opis.asp?id=20

MAas S., Detzel P. \& STAudT A. 2002. Gefährdungsanalyse der Heuschrecken Deutschlands - Verbreitungsatlas, Gefährdungseinstufung und Schutzkonzepte. Bundesamt für Naturschutz, Bonn-Bad Godesberg, $401 \mathrm{pp}$.

Rust C., Schwebel L. \& SARDET E. 2012. Modicogryllus frontalis (Fieber, 1844), espèce nouvelle en France (Orthoptera, Gryllidae). Matériaux orthoptériques et entomocénotiques 17: 57-62.

SzÖVÉNYI G. 2011. First record of Modicogryllus truncatus in Hungary (Orthoptera: Gryllidae). Folia Entomologica Hungarica. 72: 9-12.

TROPEK R. 2013. Faunistic records from the Czech Republic - 354. Orthoptera: Gryllidae. Klapalekiana 49: 226.

\section{STRESZCZENIE}

\section{[Pierwsze stwierdzenie Modicogryllus frontalis (Orthoptera: Gryllidae) na Wybrzeżu Baltyckim]}

Świerszczyk szary Modicogryllus frontalis jest gatunkiem zagrożonym w Polsce i w innych krajach centralnej Europy, gdzie zniknął z wielu wcześniejszych stanowisk. Północnozachodnia granica zasięgu tego gatunku przebiega przez Francję, Niemcy, Czechy, Polskę i Litwę. Jedną nimfę M. frontalis znaleziono pod Czołpinem (północna Polska) na wydmach piaszczystych, niedaleko od wybrzeża Bałtyku. To najdalej na północ wysunięte stanowisko tak dla Polski jak i Europy. Jest również pierwszym stwierdzeniem na Wybrzeżu Bałtyckim. Autorzy wskazują na potrzebę badań populacyjnych na tym stanowisku oraz poszukiwań tego gatunku w innych miejscach wzdłuż Wybrzeża Bałtyckiego. 